Western University Scholarship@Western

1999

\title{
Endogenous Effort and Intersectoral Labour Transfers Under Industrialization
}

Madanmohan Ghosh

John Whalley

Follow this and additional works at: https://ir.lib.uwo.ca/economicsresrpt

Part of the Economics Commons

Citation of this paper:

Ghosh, Madanmohan, John Whalley. "Endogenous Effort and Intersectoral Labour Transfers Under Industrialization." Department of Economics Research Reports, 9908. London, ON: Department of Economics, University of Western Ontario (1999). 


\title{
RESEARCH REPORT 9908
}

\author{
Endogenous Effort And Intersectoral Labour \\ Transfers Under Industrialization \\ ECONOAACS REFERERICE CENTRE \\ by \\ MAR - 82000 \\ Madanmohan Ghosh and John Whalley \\ UASVERSITY OF WESTERN ONTRAOP
}

October 1998

\author{
Department of Economics \\ Social Science Centre \\ University of Western Ontario \\ London, Ontario, Canada \\ N6A 5C2 \\ econref@julian.uwo.ca
}




\title{
ENDOGENOUS EFFORT AND INTERSECTORAL LABOUR TRANSFERS UNDER INDUSTRIALIZATION ${ }^{1}$
}

\author{
Madanmohan Ghosh \\ University of Western Ontario
}

\author{
John Whalley \\ Universities of Warwick and Western Ontario and NBER
}

October 22, 1998

\begin{abstract}
This paper discusses the welfare and one time growth effects from the intersectoral labour transfers that typically accompany early industrialization in the developing countries, suggesting that endogenous determination of effort is key to evaluating their significance. The significance of these transfers for growth performance has been discussed in recent literature, which focuses on capital accumulation as the engine of growth. We begin with traditional Lewis models, where an efficiency gain results from transferring labour from the traditional (family based) agricultural sector, in which labour receives its average product, to the modern (industrial) sector in which labourers are paid their marginal product. We show that as one moves closer to Pareto Optimality in this system (say by taxing the traditional sector's output), there is a gain but this is typically small. We then formulate Lewis type models in which the product of effort and labour enters each sector's production function, and individuals in the traditional sector only receive a fraction of the return to their incremental effort due to average product pricing of labour. In this case, the level of effort in each sector, is endogenously determined along with the intersectoral allocation of labour, since the representative household is modeled as having a utility function defined over goods along with the disutility of effort. Differences in effort levels across sectors support accompanying differences in average and marginal products of labour. We use this model to analyze growth processes in Thailand and South Korea over the period between the 1960s and 1990s. Results suggest significant contributions to growth from intersectoral labour transfers in Lewis models with endogenous effort, and negligible contributions from models without endogenous effort.
\end{abstract}

Key Words: Endogenous effort, labour transfers and growth.

JEL Classification No: 047

${ }^{1}$ We are grateful to Norman Ireland and Jeff Round for discussion of the issues taken up here, and participants in a seminar at Western Ontario. 


\section{Introduction}

Twenty years ago, it was common both in development courses and in the literature more generally to focus on the development process as one revolving centrally around the transfer of labour from the agricultural sector to a modern industrial sector. This was Polanyi's (1944) great transformation; labour flowing from an initially dominant agricultural sector into fledgling labour intensive manufacturing industries (such as textiles and apparel), with the economy then moving up a technology ladder to more sophisticated but still labour intensive manufacturing (e.g., furniture), and onto heavy industry (such as steel, chemicals), and eventually higher technology products. As this process advanced, more and more labour would move out of the agricultural sector, and labour productivity in both agriculture and manufacturing would rise, with significant growth in living standards the result. Later authors who also emphasized the role of intersectoral labour transfers as the key to economic growth included Lewis (1954), Fei and Ranis (1964) and Chenery and Syrquin ${ }^{1}$ (1975). This characterization, it was alleged, fitted the industrial revolution in the UK (and a little later elsewhere in Europe and in North America), and also subsequent growth, such as that we have seen in recent years in Asia. As successive transformations have occurred they have also become successively shorter in duration (comparing Europe and Asia for example).

Today, authors such as Krugman (1994) and Rodrik (1997) place less weight on this transformation process as providing the engine of growth when discussing growth performance in Asia $^{2}$. They instead focus on high rates of physical and human capital formation reflecting large financial savings. Drawing on Young $(1993,1994)$ Krugman (1994) has argued that recent high growth rates in Asia largely reflect high rates of input growth, not the contribution of intersectoral transfers of labour. This is even to the point that claims have been made that accumulated inputs 
have not always been employed in the most efficient manner, since factor accumulation in some cases seems to more than account for observed growth ${ }^{3}$.

We argue here that while existing literature provides no clear analytical reasons why there could be large one time growth effects from intersectoral labour transfers; there is nonetheless some intuition, as to why this could be so $^{4}$. We start from the Lewis (1954) labour surplus economy model, later elaborated on by Fei and Ranis (1964), in which there is a traditional (family based) agricultural sector in which labour receives his/her average product, and a modern (industrial) sector where there is marginal product pricing of labour. Our innovation is to formulate a model in the spirit of Lewis in which not only is the intersectoral allocation of labour endogenously determined, but also the level of effort that workers apply while at work in each sector. Importantly, with marginal product pricing of labour in the modern (industrial) sector, labour employed here will receive the full marginal return to any additional effort, but the sharing rule implied by average product pricing of labour in traditional agriculture implies that in this sector only a small portion of any return from incremental effort accrues to the individual supplying $i^{6}$. Wage differentials across sectors are therefore accompanied by effort differentials across sectors.

In a simple (no effort) Lewis world there is an efficiency gain to be had by transferring labour from average product pricing of labour in agriculture marginal product pricing in the modern (industrial) sector. This moves the economy closer to Pareto optimality, but typically the size of such gains is small. If we formulate a simple two sector general equilibrium model in which, unlike in Lewis, the product of effort and labour input enters each sector's production function, we can model a representative household with a utility function defined over goods, and disutility of effort supplied to the two sectors. In equilibrium, differences in average and marginal products of labour across 
sectors are supported by sectoral differences in effort levels. Once endogenous effort and the disincentive effects of supplying additional effort are incorporated in this way, that contribution of intersectoral labour transfers can be much larger. Labour transfers move labour from low effort to high effort sectors, and also reduce the team size in the traditional sector. Given an average product sharing rule, the effects can sharply increase both effort and aggregate labour productivity.

We use such a model to analyze growth processes in Thailand and South Korea between the 1960s and 1990s. Calibration of these models to base case model specifications inevitably involves uncertainty over key parameters, but we are able to show ranges of effects in our results which suggest a significant contribution from Lewis models with endogenous effort in accounting for growth in these economies, and only a negligible contribution from comparable Lewis models without endogenous effort. Model results suggest that depending on the parameterization used, intersectoral labour transfers in an endogenous effort model can account for around one quarter of the growth that has taken place over the last thirty years in these economies. In a no effort model, in contrast, the contribution is negligible. A similar structure would also amplify the estimated gains from removal of average product labour pricing in state owned enterprises in transition economies undergoing reform, where low effort levels is also the issue.

We set out our analytical model with endogenous effort in section 2 . We discuss data and parameterization of the model in section 3 . Section 4 analyzes the results from country simulation exercises, and some concluding remarks are made in section 5. 


\section{A Two Sector Model With Endogenous Effort}

\section{Overview}

To analyze the contribution of intersectoral resource transfers to growth in a Lewis type model with endogenous effort, we consider an economy consisting of 2 sectors (traditional and modern) and a fixed number of identical households, $\mathrm{N}$, which we treat as consolidated for demand side purposes into a single representative consumer. Each of these households is endowed with $L / N$ units of physical labour (time), where $\mathrm{L}$ denotes the economy wide labour (time) endowment. In the traditional (agricultural) sector workers are paid their average product, while in the modern (manufacturing) sector labour is paid its marginal value product. Given a team size $\mathrm{N}_{\mathrm{T}}$ as the organizational unit for production in the traditional sector, this specification implies that a worker (or unit of labour) receives only a portion $\left(1 / \mathrm{N}_{\mathrm{T}}\right)$ of the return from extra effort, while she/he receives the full return in the modern sector.

The representative household derives utility from consumption of goods but dislikes effort provided when working. The household generates income by selling labour services to the traditional (agricultural) sector and/or the modern (industrial) sector. The household also receives rents from fixed factors used in production. The household chooses the level of effort in each sector that equalizes the marginal disutility of effort and the marginal utility of consumption resulting from extra income generated by effort. In equilibrium, intersectoral differences in income per unit of labour are accommodated by intersectoral differences in effort levels.

\section{Model Structure}

Production $\left(X_{i}\right)$ in each sector $(i=$ traditional sector $(T)$, and modern sector $(M))$ is given by the production function 


$$
X_{i}=\Phi_{i}\left(E_{i} L_{i}\right)^{\alpha_{i}} \quad i=(T M) ; \quad 0<\alpha_{i}<1
$$

where $L_{i}$ is the labour used in sector $i, E_{i}$ is the level of effort supplied by labour working in sector $i, \phi_{i}$ is the scale parameter in production in sector $i$, and $\alpha_{i}$ is the labour share parameter. Since $\alpha_{i}$ $<1$, these are decreasing returns to scale production functions. Rents accrue to owner/managers in the modern sector where labour is paid its marginal product, while no rents accrue in the traditional sector where labour receives its average product. The product term, $\mathrm{E}_{\mathrm{i}} \mathrm{L}_{\mathrm{i}}$, defines the effective labour input in production in sector i in efficiency units.

The wage rate in the modern sector, $\mathrm{W}_{\mathrm{M}}$, is given by the marginal value product of labour

$$
W_{M}=\phi_{M} P_{M}^{\alpha_{M}} E_{M}^{\alpha_{M}} L_{M}^{\alpha_{M}-1}
$$

where $P_{M}$ is the price of goods produced in the modern sector.

In the traditional sector we denote the value of the average product of labour, $\mathrm{W}_{\mathrm{T}}$ as

$$
W_{T}=\phi_{T} P_{T} E_{T}^{\alpha_{T}} L_{T}^{\alpha_{T}-1}
$$

where $\mathrm{P}_{\mathrm{T}}$ is the price of goods produced in the traditional sector.

Rents in the modern sector are treated as part of the income of the representative household, and are given by the difference between the total value of production and payments to labour

$$
R=P_{M} X_{M}-W_{M} L_{M}
$$


Household income (I) comprises of income from labour in the traditional sector $\left(W_{T} L_{T}\right)$, and the modern sector $\left(W_{M} L_{M}\right)$, and rents $(R)$ i.e.,

$$
I=\sum_{i=T, M} W_{i} L_{i}+R
$$

where $\mathrm{W}_{\mathrm{T}}$ and $\mathrm{W}_{\mathrm{M}}$ are the per person returns to labour in the traditional and modern sectors respectively.

We assume that all households have identical preferences defined over goods and the negative of effort in each of the two sectors. We represent these preferences by a separable utility function for the representative household, defined over the goods produced by the two sectors, $u(C)$, and two disutility sub functions defined over the effort levels per unit labour, multiplied by labour supplied to each sector i.e.,

$$
U(C, E)=u(C)-L_{\tau} v\left(E_{\tau}\right)-L_{M} v\left(E_{M}\right)
$$

For generality, we write $v\left(E_{i}\right)$ is the disutility of effort for the representative household per unit of labour in each sector supplied to sector $i$, and each sub function is multiplied by the employment in each of the two sectors.

Utility maximizing behaviour determines how much is consumed, and how much labour and effort is supplied to each sector. We assume $u(C)$ is a CES function, and demands for goods $\left(C_{i}\right)$ are given by

$$
C_{i}=\frac{\beta_{i} I}{P_{i}^{c^{0}} \sum_{j} \beta_{f} P_{j}^{c^{1 \cdot \theta}}} \quad i=(T, M)
$$


where $I$ is the income of the representative household, $\beta_{i}$ is the share parameter on good $i$ in consumption, and $\theta$ is the elasticity of substitution in consumption.

The marginal utility from additional income spent on goods, $\mu$, in this case is

$$
\mu=\left[\sum_{i} \beta_{i} P_{i}^{c^{1-\theta}}\right]^{\frac{1}{\theta-1}}
$$

We follow MacMillan, Whalley and Zhu (1989) in using a functional form for each disutility of effort sub function $v\left(E_{i}\right)$ as,

$$
v\left(E_{i}\right)=\frac{E_{i}^{2}}{z \delta} \quad \text { where } v^{\prime}\left(E_{l}\right)>0, v^{\prime \prime}\left(E_{i}\right)>0 \quad \delta>0
$$

where $z$ defines the elasticity of the disutility of effort for sector $i, \delta$ is a unit parameter. For simplicity, we later treat these functions as identical across the two sectors, and note that the marginal disutility of effort, $\mathrm{E}_{\mathrm{i}}^{z-1} / \delta$, increases with effort. In determining the curvature of the effort disutility function, the $\mathrm{z}$ parameter operates in an analogous way to the coefficient of relative risk aversion in analysis of behaviour towards risk. The sign of the second derivative of this function depends on whether $\mathrm{Z}$ is greater or less than one.

$$
\frac{\delta^{2} v_{i}}{\delta E_{i}^{2}}=(z-1) \frac{E_{i}^{z-2}}{\delta} \quad(i=T, M)
$$

Given this specification of the effort disutility function, optimizing behaviour with respect to effort in the modern sector where labour is paid its marginal product, yields 


$$
\phi_{M} \alpha_{M}^{2} P_{M}\left(L_{M} E_{M}\right)^{\alpha_{M}-1} \cdot \mu=\frac{E_{M}^{z-1}}{\delta}
$$

In contrast, income from additional effort in the traditional sector is shared equally with all team workers employed in that sector, and optimizing behaviour with regard to the level of effort in this sector yields

$$
\phi_{T} \alpha_{T} P_{T}\left(L_{T} E_{T}\right)^{\alpha_{T}-1} \mu=\frac{E_{T}^{z-1}}{\delta}
$$

Households allocate labour between sectors such that

$$
\mu W_{M}-E_{M}=\mu W_{T}-E_{T}
$$

Equilibrium in this model is characterized by market clearing in the labour market (equation 16 below), market clearing for goods (equation 17, below) and the conditions given in equations (13) - (15) for optimizing behaviour with respect to effort in each sector; i.e.,

$$
L=L_{T}+L_{M}
$$

We later use commodity tax and subsidy parameters as a way of generating intersectoral labour transfers, choosing tax and subsidy rates for the counterfactual analyses performed with the model so as to replicate the actual intersectoral labour transfers occurring in the economy over the period of time under consideration (i.e., in Thailand and Korea from the late 1960s to the early 
1990s). The two output prices, gross of commodity taxes (or subsidies), $P_{i}^{c}$, one net of taxes (or subsidies), $P_{i}$ are related through the tax rate and subsidy rates, $t_{i}$ as

$$
P_{i}^{c}=P_{i}\left(1+t_{i}\right) \quad i=(T, M)
$$

where $t_{i}$ is the tax (subsidy) rate on consumption of good $i$. In our counterfactual analyses, these taxes and subsidies are set up as a zero revenue raising scheme meeting the constraint that

$$
\begin{array}{cc}
\sum_{i=T, M} P_{i} t_{i} C_{i}=0 & i=(T, M) \\
X_{i}=C_{i} & (i=T, M)
\end{array}
$$

This model has 16 variables $\left(X_{i}, E_{i}, L_{i}, W_{i}, P_{i}, C_{i}, R, t_{i}\right.$ (subsidy rate), I and $\mu$ ). We fix one of the goods prices as the numeraire, and we are able to solve it numerically for an equilibrium by using the Generalized Algebraic Modelling System (GAMS) software (Brooke, Kendrick and Meeraus, 1997). As in traditional applied general equilibrium modeis (see Shoven and Whalley, 1992) we can calibrate the model to a base case equilibrium data set, from which we can determine parameter values such that the model solution replicates the base case equilibrium. We can then solve for counterfactual equilibria given changes in the model specification (tax or subsidy rates).

Specifically, we can calibrate specification of the model to model base year admissible data sets for 1968 (Korea) and 1975 (Thailand) respectively, in which the share of the labour force in the modern sector was relatively small. We can then introduce a tax on traditional sector output and or a subsidy on the modern sector output which in combination raise zero revenue and generate a new equilibrium in which the share of the labour force in the modern sector replicates that observed in a 
terminal year (1994 for each economy). To achieve this, tax rates are parametrically varied (with subsidy rates endogenously determined for zero revenue) until an equilibrium in which the intersectoral composition of labour observed in the terminal year is reached. In the base case, significant wage differentials exist between the modern and the traditional sector, and as a result effort levels are substantially lower than in the modern sector. Labour transfers generated in this way in the model raise real income and generate a gain, which we can in turn compare to the actual gain in real income over the sample period. 


\section{Data and Parameterization of the Model}

Our strategy in using this model to evaluate the role of intersectoral labour transfers in the growth experiences of Korea and Thailand is to first calibrate the model described above to base case data sets for each of the two economies at the beginning of the sample period (1968 for Korea and 1975 for Thailand). We can then use a zero revenue raising combination of a tax on agricultural output and a subsidy on manufacturing output to induce a flow of labour between sectors in the model so as to yield the same sectoral composition of labour as that actually observed in the terminal year of the sample period for each economy (1994 for both Korea and Thailand). The s e $t$ wo economies have been used in these computations because each has experienced rapid growth while also undergoing major structural transformation, with substantial transfers of labour occurring out of the agricultural sector. Table 1 indicates a decline in the share of the labour force in agriculture from 53.7 per cent to 13.8 per cent in Korea over the period, and from 53.7 per cent to 56.1 in Thailand. The compound annual growth rate of real income per capita over the period was 5.5 per cent in Korea and 6.3 per cent in Thailand. It is also the case that for these two economies we can relatively easily obtain data on GDP growth and labour force composition from UN Statistical sources.

In making calculations of the role of intersectoral labour transfers in Korea and Thai growth over these periods, we use the applied general equilibrium techniques set out in Shoven and Whalley (1992), involving model calibration and counterfactual equilibrium analysis. The differences from standard application of these procedures are the use of a more complex model structure, and a focus on expost decomposition of actual changes observed in data into component factors. 
Table 1

Summary Statistics on Thai and Korea Growth Performance

\begin{tabular}{|l|c|c|c|c|}
\hline & \multicolumn{2}{|c|}{ Korea } & \multicolumn{2}{c|}{ Thailand } \\
\hline & 1968 & 1994 & 1975 & 1994 \\
\hline $\begin{array}{l}\text { GDP Per Capita in Constant } \\
1990 \text { prices (in thousand) }\end{array}$ & 2.95 Won & 11.9 Won & 16.2 Baht & 51.4 Baht \\
\hline $\begin{array}{l}\text { Annual compound growth rate of per } \\
\text { capita GDP over sample Period }\end{array}$ & \multicolumn{3}{|c|}{5.5} & \multicolumn{2}{c|}{6.3} \\
\hline Share of Labour Force in agriculture & 53.7 & 13.8 & 73.1 & 56.1 \\
\hline
\end{tabular}

Table 2

\begin{tabular}{|l|l|l|}
\hline \multicolumn{2}{|c|}{ Basic Data Sources by Country } \\
\hline Korea & Thailand \\
\hline Labour Force Composition Data & UN (1975, Table II, Pages & UN (1980, Table II, Pages \\
& $219-220,1996$, Table II, & $\begin{array}{l}482,1996, \text { Table II, Page } \\
544)\end{array}$ \\
\hline Page 454) & UN (1975, Table III, Pages & UN (1980, Table III, Pages \\
& 220,1996, Table III, Page & $\begin{array}{l}483,1996, \text { Table III, Page } \\
545)\end{array}$ \\
\hline Output Composition Data & $455)$ & UN (1978, Table 5, Page \\
Compensation Data & UN (1978, Table 5, Page & $1156)$ \\
\hline
\end{tabular}

We use data from the United Nations Yearbook of National Accounts Statistics, and the Statistical Yearbook for Asia and the Pacific for various years as the starting point for building model admissible data sets (detailed in Table 2). To construct base case data sets for use in model calibration, several adjustments are made to the raw data. Agriculture and mining are grouped together as a single traditional sector, and remaining sectors are aggregated to provide data on the modern sector. We use employment data (including self employment) to give estimates of sectoral labour composition in each economy on which we focus. Value added data show a high share of 
capital income for the traditional sector in both countries, which reflects the fact that the proportion of hired labour (paid workers) in the traditional (agricultural) sector is small and that the labour income of family members is included in the operating surplus for this sector, and adjustments are made in light of this. Average compensation of employees (wage rate) in manufacturing are around 13 times and 6 times of that in the traditional sector in Thailand and Korea respectively. For Thailand we adjusted this by adding $1 / 3 \mathrm{rd}$ of operating surplus in agriculture to compensation of employees arriving at a wage ratio of 3.5 between manufacturing and agriculture. To derive Korean wage rate in agriculture for the base year we add 40 per cent of operating surplus in agriculture with compensation to employees yielding a wage ratio of 2.1 between manufacturing and agriculture. This we had to do as with higher wage dispersion we found problems solving the model numerically. Table 3 sets out the level values used as the base case inputs to calibration in each country analysis. Labour in the traditional and modern sectors in thousands is reported for the base (initial) years of 1968 (Korea) and 1975 (Thailand). Output in value terms is similarly reported for the base case years for each economy. Finally, we list values for the ratios of wages (wage rates in the modern sector to average product in the traditional sector) across the sectors. The latter are key elements of the base case data, because the larger the wage rate dispersion in the base case data, the larger the gain in real income that will occur from generating intersectoral labour transfers in the model not reported in the paper. As mentioned above wage dispersion on the basis of wage rates calculated from compensation to employees are very high both for Thailand and Korea compared to what we report in Table 3. Another reason for downward revision of these estimates is to reflect human capital differences across sectors. A lower base case wage dispersion implies a smaller effort differential across sectors, and smaller gains from any intersectoral reallocation of labour. 
Table 3

Dáta and Resulting Model Parameterization Used in Base Case Analyses

A: Base Case Level Values ${ }^{1}$ Used as Input to Calibration

\begin{tabular}{|l|c|c|}
\hline & Korea (1968) & Thailand (1975) \\
\hline Labour in Traditional Sector (in thousands) & 4977 & 13298 \\
\hline Labour in Modern Sector (in thousands) & 4284 & 4883 \\
\hline Value of Output in Traditional Sector & 461 (bill Won) & 95.8 (bill Baht) \\
\hline Value of Output in Modern Sector & 865 (Bill Won) & 152.8 (bill Baht) \\
\hline $\begin{array}{l}\text { Ratio of Wage in Modern to Traditional } \\
\text { Sector }\end{array}$ & 2.1 & 3.5 \\
\hline
\end{tabular}

B. Parameter Values Set Exogenously for Calibration

\begin{tabular}{|l|r|r|}
\hline & Korea & Thailand \\
\hline$Z$ (curvature of dis-utility of effort function) & 2.0 & 2.0 \\
\hline$\theta$ (elasticity of substitution in goods sub-utility function) & 1.5 & 1.5 \\
\hline
\end{tabular}

C. Parameter Values Endogenously Determined via Calibration

\begin{tabular}{|l|r|r|}
\hline & Korea & Thailand \\
\hline$\delta$ (units term in dis-utility of effort function) & 0.629 & 0.950 \\
\hline$\alpha_{\mathrm{T}}$ (Production function share parameter in traditional sector) & 0.287 & 0.216 \\
\hline$\alpha_{\mathrm{M}}$ (Production function share parameter in modern sector) & 0.982 & 0.816 \\
\hline $\mathrm{E}_{\mathrm{T}}$ (Effort level in traditional sector) & 0.409 & 0.385 \\
\hline $\mathrm{E}_{\mathrm{M}}$ (Effort level in modern sector) & 1.106 & 1.406 \\
\hline$\phi_{\mathrm{T}}$ (Units term in traditional sector production function) & 19.41 & 41.01 \\
\hline$\phi_{\mathrm{M}}$ (Units term in modern sector production function) & 1.96 & 4.84 \\
\hline$\alpha_{\mathrm{T}}$ (Consumption share parameter for traditional sector goods) & 0.348 & 0.386 \\
\hline$\alpha_{\mathrm{M}}$ (Consumption share parameter for modern sector goods) & 0.652 & 0.614 \\
\hline
\end{tabular}

1 Source: As in Table 2

2 Note: See text for further discussion. 
After determining the base case level values, we set two model parameters exogenously. Z, which determines the elasticity of the disutility of effort function, is set at 2. MacMillan, Whalley and Zhu (1989) use a higher value in their central case of team incentives in China. We have undertaken some sensitivity tests varying $Z$ upward and downward. $\theta$, the elasticity of substitution among goods, we set at 1.5. $\theta$ determines the strength of demand side substitution effects, and hence influences the change in intersectoral labour allocation for any given tax-subsidy combination.

Together, these base case level values and exogenous parameter values allow us to determine the remaining model parameter values through calibration. The share parameters in production that result are low in each traditional sector production function, but high in each modern sector. Given the wage rate differentials prevailing in the base cases, effort levels are low (high) in traditional (modern) sectors. In turn, units terms are high in traditional sector production functions, but low in modern sector production functions reflecting the differences in effort levels generated in the base case across sectors through calibration. Effort levels are hard to measure directly, even though we might expect effort to be related to the number of hours worked, bonuses paid, and the physical, intellectual and mental limits to performance of labour (Boswerth, 1976). We obtain an indirect measure of effort by calibrating the parameters in the disutility function on the basis of the wage differential that exists between the sectors in each economy in the base case.

The returns to scale parameter or share parameter, $\alpha$ in production is determined through calibration and its value depends on $Z, \delta$ and wage dispersions between sectors. A higher $Z$ for example results in a lower value of calibrated $\alpha$ parameter for agricultural sector. Similarly, a higher wage dispersion yields a higher dispersion in $\alpha$ parameters between sectors; $\alpha$ for agriculture becomes smaller and $\alpha$ in the manufacturing becomes larger. This is but to support the wage differences across 
sectors given the values of exogenous parameters. Due to the very non-linear model structure particularly the effort dis-utility function, calibration of parameters are highly sensitive to specification of exogenous parameters and wage dispersions. We also encountered incidences of multiplicity of equilibria in our model calibration, but the basic thrust of the results remain the same.

With the calibration and parameterization complete, we are then in a position to use the model for decompositional analysis to estimate the proportion of the actual growth over the sample period in Korea and Thailand that can be attributed to intersectoral labour transfers. 


\section{Model Results}

We compute counterfactual equilibria for each model, with tax and subsidy rates applied to the outputs of the traditional and modern sector respectively such that the proportion of the labour force in the counterfactual model solution for each economy is the same as in the terminal year (1994, see Table 1). These are combined as zero revenue tax and subsidy schemes, and used to estimate the contribution of intersectoral labour transfers to growth performance in Korea and Thailand over the two sample periods under consideration. A real income gain accrues to each economy as labour moves from low effort to high effort sectors. We measure the real income gain in terms of a money metric measure of the changes in the utility of goods function ${ }^{7}$. We ignore the disutility of effort function in our welfare computations as we relate the size of the gain in real income in the model from intersectoral labour transfers to measured increases in real GDP per capita, which also exclude any disutility of effort.

In counterfactual mode, the model produces a once and for all increase in real income in the base year for the intersectoral labour transfers we generate by taxes and transfers, which we relate to the actual compound growth over the period (of more than two decades) for each economy. The procedures we employ are set schematically in Figure 1. A and B denote actual observation of GDP per capita in each of the economies over the sample period. Our counterfactual model solutions which induces intersectoral labour transfers comparable to those observed in the terminal year induces a gain which we, for now, assume occurs fully in the base year, moving real income per capita to point $C$. The ray $\mathrm{CB}$ implies a lower compound growth rate over the period than along the observed ray $\mathrm{AB}$, with the implicit assumption that the same gain from intersectoral labour transfers once realized is fully present in each succeeding year. This implies a growth ray $\mathrm{AD}$ as the modified growth path for 
Korea (Thailand) without intersectoral labour transfers, yielding an estimate of the ratio of the two areas $\mathrm{W}$ to $(\mathrm{W}+\mathrm{Z})$ as the proportion of actual growth over the period which we attribute to intersectoral labour transfers. As displayed in Figure 1, this procedure involves the strong assumption that the real income gain from intersectoral labour transfers occurs in full form in the first year of the sample period, and repeats itself period after period. We can also use these procedures assuming there is a delay to the arrival of the real income gain from the intersectoral labour transfers. These delays are varied in alternative analyses. For space reasons, we have not drawn this case, but this lowers the portion of the real income gain attributable to intersectoral labour transfers. In our central case analysis, we assume a full gain arrives in the mid year of the sample period.

Table 4 reports central case results from the application of these procedures the two country models. We first report annual compound growth rates of GDP per capita for both the economies over the sample period, along with the implied compound growth multiple. When we use the model in counterfactual mode to calculate the gains from intersectoral labour transfers, large once and for all effects are obtained; 38 per cent of base case income in Korea and 25 per cent in Thailand. These large effects stand in sharp contrast to the small welfare effects of tax and subsidy distortions usually obtained in no effort models. Importantly they are positive here for the taxes and subsidies we consider rather than negative in conventional Lewis models as such high taxes, in the no effort case, over correct for the distortion from average product pricing of labour. 


\section{Figure1: Procedures For Attributing A Portion of Actual Growth in Korea (Thailand) to Intersectoral Transfers}

Key

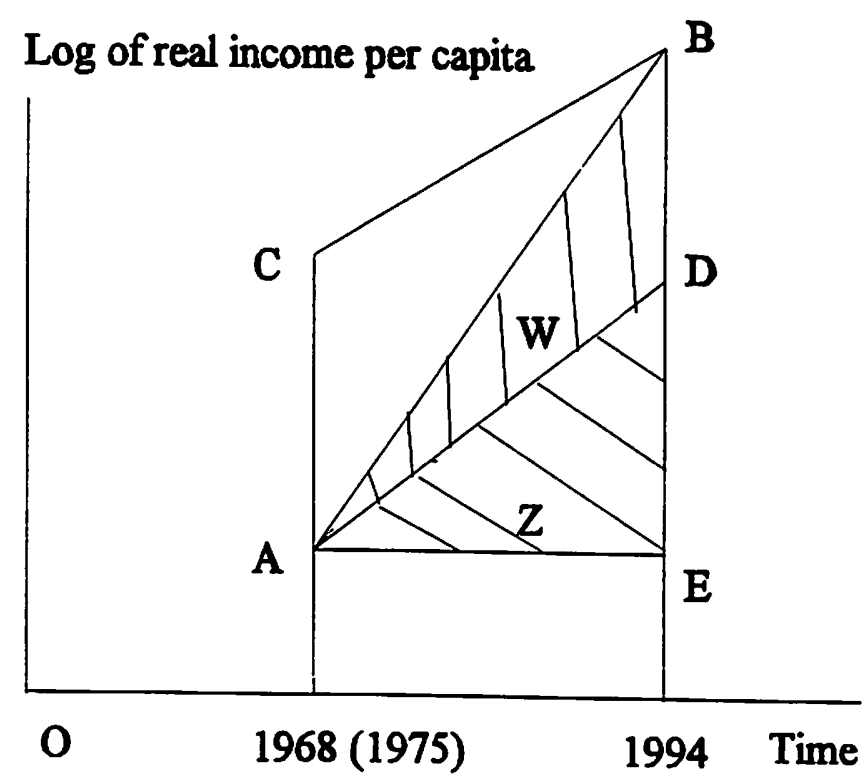
A: Observed GDP/capita in base year
B: Observed GDP/capita in terminal year
C: $\quad$ Model generated counterfactual equilibrium with intersectoral labour transfers in model proportional terms in the base year
D: Terminal year GDP/capita with slower growth (as along the ray $\mathrm{CB}$ ) with the gain from intersectoral transfers in place each year
E: Zero growth GDP/capita measure
Z: GDP growth after modification for intersectoral transfer effect
$\mathrm{W}$ : component of actual growth attributed to intersectoral transfers $\mathrm{W} /(\mathrm{W}+\mathrm{Z})$ : proportion of actual growth attributed to intersectoral transfers. 


\section{Table 4 \\ Decomposition Analyzes of Korean and Thai Growth \\ Using Base Case Model}

A. Actual Growth Performance in Korea and Thailand

\begin{tabular}{|l|c|c|}
\hline & Korea (1968-94) & Thailand (1975-94) \\
\hline $\begin{array}{l}\text { Annual compound growth } \\
\text { rate of real GDP per labour } \\
\text { force participant over the } \\
\text { period }\end{array}$ & 5.5 & 6.3 \\
\hline $\begin{array}{l}\text { Compound growth multiple } \\
\text { of per labour force participant } \\
\text { real GDP over the period }\end{array}$ & 4.04 & 3.17 \\
\hline
\end{tabular}

B. Real Income Gain in Model by using a Resource Transfer Equivalent (RTE) Tax-Subsidy

\begin{tabular}{|l|c|c|}
\hline & Korea & Thailand \\
\hline $\begin{array}{l}\text { Real income gain under RTE Tax- } \\
\text { Subsidy as per cent of base GDP per } \\
\text { capita }\end{array}$ & 37.9 & 25.0 \\
\hline $\begin{array}{l}\text { Fraction of growth accounted for by } \\
\text { intersectoral resource transfers (see } \\
\text { Figure 1 and discussion in Text) }\end{array}$ & 26.9 & 22.6 \\
\hline $\begin{array}{l}\text { Tax rate on traditional sector output } \\
\text { needed to achieve 1994 labour force } \\
\text { composition between traditional and } \\
\text { modern sector }\end{array}$ & 320 & 56 \\
\hline
\end{tabular}

Using the procedures set out in Figure 1 to assess the contribution of intersectoral labour transfers to growth using this structure produces yields estimates of around 27 percent for Korea and 23 per cent for Thailand: a strikingly large figure relative to current literature discussion.

Table 5 reports parameter sensitivity analyses of the these findings. First we vary the elasticity of substitution in consumption. As this falls, the output composition change accompanying the observed intersectoral reallocation of labour yielding smaller welfare and hence real income gains. 
Second we vary the curvature of the disutility of effort functions $(Z)$ over the solution range; higher $Z$ values, not surprisingly raise the estimates of the portion of growth attributed to observed intersectoral labour transfers and lower value of $Z$ lowers the estimates of the gain. Thus while sensitivity of results occurs, it is not of a degree that reverses the basic thrust of results. Finally, we vary both the curvature parameter and elasticity parameter; with higher values of $\mathrm{Z}$ and $\theta$ the estimates of the portion of growth attributable to intersectoral labour transfers are further higher. Thus from Table 4 depending upon the parametric specification the estimated contribution of the intersectoral labour transfers from traditional sector to modern sector in overall economic growth over the past 20 to 30 year period lies in the range of 24 to 32 per cent and for Thailand it ranges from 22 to 24 per cent. A lower contribution of intersectoral labour transfers in Thai growth process compared to that of Korea is due to smaller transfers in the Thai case.

In Table 6, we report sensitivity analyses of results with respect to the procedures we set out in Figure 1. Specifically, assuming a delay in the starting point of the real income gain does significantly affect results, although intersectoral labour transfers continue to play a role in the observed growth process. 
Table 5

Sensitivity Analyses of Decompositional Findings of Table 4

to Model Parameters and Assumptions

\begin{tabular}{|c|c|c|}
\hline & $\begin{array}{l}\text { Fraction of } 1968-94 \text { Korean } \\
\text { growth accounted for by } \\
\text { resource transfer equivalent } \\
\text { tax-subsidy in } 1968\end{array}$ & $\begin{array}{l}\text { Fraction of } 1975-94 \text { Thai } \\
\text { growth accounted for by } \\
\text { resource transfer equivalent } \\
\text { tax-subsidy in } 1975\end{array}$ \\
\hline \multicolumn{3}{|c|}{ A: Setting of $\theta$, elasticity of substitution in consumption } \\
\hline 1.5 & 26.9 & 22.6 \\
\hline 1.0 & 23.7 & 21.6 \\
\hline 3.0 & 29.3 & 23.3 \\
\hline \multicolumn{3}{|c|}{ B: Setting of $z$, curvature of dis-utility of effort function } \\
\hline 2.0 & 26.9 & 22.6 \\
\hline 1.75 & 25.4 & 22.4 \\
\hline 2.25 & 27.8 & 22.8 \\
\hline \multicolumn{3}{|c|}{$C$ : Setting of $z$ and $\theta$, together } \\
\hline $\mathrm{Z}=2.25, \theta,=2$ & 29.8 & 23.2 \\
\hline $\mathrm{Z}=2.25, \theta,=3$ & 31.6 & 24.1 \\
\hline $\mathrm{Z}=1.75, \theta,=2$ & 28.2 & 22.8 \\
\hline
\end{tabular}


Table 6

Impact of Assumed Delay in Onset of Real Income

Gains for the Portion of Growth Attributed to Intersectoral Labour Transfers

\begin{tabular}{|l|c|c|}
\hline $\begin{array}{l}\text { Assumed Delay in Onset of Real Income } \\
\text { Gains }\end{array}$ & \multicolumn{2}{|l|}{$\begin{array}{l}\text { Proportion of Observed Growth over Sample } \\
\text { Period Attributed to Intersectoral Labour } \\
\text { Transfers }\end{array}$} \\
\hline & Korea & Thailand \\
\hline O years & 32.4 & 27.0 \\
\hline $1 / 4$ of period & 31.4 & 26.2 \\
\hline $1 / 2$ of period (base case) & 26.9 & 22.6 \\
\hline $3 / 4$ of period & 16.5 & 14.8 \\
\hline
\end{tabular}

Finally, in Table 7 we report the fraction of growth attributed to intersectoral labour transfers in Korea and Thailand both for the base case with effort model, and for a comparable no effort model of traditional Lewis form. This later model is calibrated to the same data set but without effort, and in the base case income returns per unit of labour are the same across the two sectors. Because there is average product pricing of labour in the traditional sector, there is a gain from a small labour reallocation in this model, but a loss can easily result if larger reallocation occurs. We calibrate this model in a similar way to the base case model, and perform similar counterfactuals to determine the contribution of intersectoral labour transfers to growth in the no effort case.

The first row of the Table 7 are the central case results of the model with effort, but the second (without effort) row are negative. The negative effect indicates that without effort, only a relatively small labour transfers improves welfare and beyond that welfare falls. The tax/subsidy scheme need to reproduce actual labour transfers goes well beyond the optimal tax needed to correct the distortion from average product pricing of labour in the no effort case. 


\section{Table 7}

Comparing Comparable ${ }^{3}$ With Effort and Without Effort Model Results

\begin{tabular}{|l|l|l|}
\hline & $\begin{array}{l}\text { Fraction of 1968-94 Korean } \\
\text { growth accounted for by } \\
\text { intersectoral resource shift } \\
\text { generated by resource } \\
\text { transfers equivalent tax- } \\
\text { subsidy }\end{array}$ & $\begin{array}{l}\text { Fraction of 1975-94 Thai } \\
\text { growth accounted for by } \\
\text { intersectoral resource shift } \\
\text { generated by resource } \\
\text { transfers equivalent tax- } \\
\text { subsidy }\end{array}$ \\
\hline Base Case With Effort Model & 26.9 & 22.6 \\
\hline $\begin{array}{l}\text { Comparable } \\
\text { Model }\end{array}$ & - ve Effort & - ve \\
\hline
\end{tabular}

Note: ${ }^{3,4}$ Comparabilty here involves calibrating the model to the same data set, including production and consumption data, and setting related exogenous parameter values to the same values as those used in the with-effort model.

These results in combination thus serve to underscore our thesis advanced in the introduction that the conventional Lewis model without endogenous effort cannot quantitatively account for the large income gains that economies undergoing transformation in Asia and elsewhere have made over recent decades, but that a model with endogenous effort moves significantly in that direction. As growth is initiated, large wage rate differentials across sectors are typically observed; these suggest large effort differentials, and with average product pricing of labour in one sector and the marginal income return to incremental effort is diluted. Intersectoral labour transfers as well as factor accumulation may thus have been important for Asian growth.

\section{Conclusions}

In this paper we discuss the relationship between intersectoral labour transfers and growth performance in the development process. We point out that conventional Lewis (1954) models of the transformation process in developing countries stress the distortion created by average product pricing in agriculture or the traditional sector, and the incentive to use policy instruments to transfer 
labour to the manufacturing (modern) sector. These models do not explicitly incorporate the marginal disincentive effects on effort of average product pricing rules, which imply that only a smail portion of the returns to marginal effort accrues to the supplier in sector governed by such rules.

We incorporate endogenous effort into an intersectoral labour allocation model, and calibrate it to first Korean and then Thai data. Our results suggest that around 27 per cent Korean and 23 per cent of Thai growth over the 1970s and 1980s can be attributed to intersectoral labour reallocation effects. In a Lewis model with no effort, these effects are insignificant. In contrast to some of the recent writings on growth in Asia which have suggested that factor accumulation is the largest (and even sole) determinant of growth, we suggest that the transformation/industrialization process long stressed in verbal literature remains as a central factor. 


\section{References}

Bonin, John, P. (1977) "Work Incentives and Uncertainty on a Collective Farm", Journal of Comparative Economics, March, Vol. 1, pp 77-97.

Boswerth, Derek, L (1976) Production Functions: A Theoretical and Empirical Study, Saxon House, Lexington Books.

Bradley, Michael E. (1971) "Incentives and Labour Supply on Soviet Collective Farms", Canadian Journal of Economics, Vol. 4(3), August, pp 342-52.

Brooke, Anthony, David Kendrick and Alexander Meeraus (1997) Generalized Algebraic Modelling System (GAMS), The Scientific Press, USA.

Chinn, Dennis L. (1979) "Team Cohesion and Collective Labour Supply in Chinese Agriculture", Journal of Comparative Economics, December, Vol. 3, pp 375-394.

Fei, John C.H. and Ranis (1964) Development of the Labour Surplus Economy: Theory and Policy, Economic Growth Centre, Yale University, Richard D. Irwin, Inc., Illinois.

Holmstrom, Bengt (1982) "Moral Hazard in Teams", Bell Journal of Economics, Vol. 13(2), Autumn, pp 324-340.

International Labour Organization (1996) Yearbook of Labour Statistics.

Ireland, N.-J. and Law, P.J. (1980) "Incentives and Efficiency in the Kosygin Reforms", Journal of Comparative Economics, Vol. 4(1), March, pp 33-39.

Krugman, Paul (1994) "The Myth of Asia's Miracle", Foreign Affairs, November/December, Volume 73 (6), pp. $62-78$.

Kim, Jong I and Lawrence J. Lau (1993) The Role of Human Capital in the Economic Growth of East Asian Newly Industrialized Countries, mimeo, Standard University.

Kim, Jong I and Lawrence J. Lau (1994) "The Sources of Economic Growth of the East Asian Newly Industrialized Countries", Journal of the Japanese and International Economies, Vol.8(3), September, pp 235-71.

Lewis, W.A (1954)"Economic Development with Unlimited Supplies of labour”, The Manchester School of Economic and Social Studies. Vol. XXII (2), May, pp. 139-91.

Liu, Minquan (1991) "Intersectoral Labour Allocation on China's Communes: A Temporal-Priority Analysis", Journal of Comparative Economics, Vol. 15, pp 602-626. 
Macmillan, J., J. Whalley and L. Zhu (1989) "The Impact of China's Economic Reforms on Agricultural Productivity Growth”, Journal of Political Economy, Vol.97 (4), pp. 782-807.

McCombie, J.S.L (1980) “On the Quantitative Importance of Kaldor's Laws", Bulletin of Economic Research, Vol. 32.

McCombie, J.S.L (1991) "The Productivity Slowdown of the Advanced Countries", Australian Economic Papers, June, pp 70-85.

Polanyi, K. (1944) The Great Transformation, Farrar \& Rinehart, Inc, New York.

Putterman, Louis (1980) "Voluntary Collectivization: A Model of Producer Institutional Choice", Journal of Comparative Economics, June, Vol. 4, pp 125-157.

Rodrik, Dani (1997) “The 'Paradoxes' of the Successful State", European Economic Review, Vol.41, pp. 411-442.

United Nations (1975), Statistical Yearbook for Asia and the Pacific.

United Nations (1978), Yearbook of National Accounts Statistics: Main Aggregates and Detailed Tables, Vol.1.

United Nations (1980), Statistical Yearbook for Asia and the Pacific.

United Nations (1996), Statistical Yearbook for Asia and the Pacific.

Young, A. (1992)" A Tale of Two Cities: Factor Accumulation and Technical Change in Hong Kong and Singapore", NBER Macroeconomic Annual, MIT Press.

Young, A. (1994a) "Lessons from the East Asian NICs: A Contrarian View", European Economic Review Papers and Proceedings, May.

Young, A. (1994b) "The Tyranny of Numbers: Confronting the Statistical Realities of the East Asian Growth Experience, NBER Working Paper No. 4680, March. 


\section{ENDNOTES}

1. Hollis Chenery and Syrquin (1975) examined the pattern of development for numerous Third World countries during the postwar period 1950-73. As per capita income rise, they found that there was shift from agricultural to industrial production. They found that there is a shift of labour out of the agricultural sector into the industrial and services sector. On this process labour productivity in the agricultural sector grows slowly in the early phase and equals that of the industrial sector only on completion of the transition. However, total labour productivity rises in the economy as a whole.

2. Rodrik (1997) suggests that East Asian growth is a miracle of accumulation rather than of growth in total factor productivity. Other writers also argue that high growth in most of the countries of the region has been largely driven by a high rate of capital accumulation of both physical and human capital. See for example, Kim and Lau (1993,1994), Young $(1992,1993,1995)$.

3. There has also been an active debate on the size of factor productivity growth in Asia.Christensen and Cummings (1981), Kim and Park (1985) and Dollar and Sokoloff (1990) estimate higher productivity growth. Young (1994), following Tsao (1982) argues that the common presumption that productivity growth in Asian NICs has been extraordinarily high, particularly in manufacturing, is largely incorrect. Young's (1994) estimates suggest that over the past two and half decades productivity growth in the NICs in aggregate ranges from -0.3 per cent in Singapore to a high of 2.3 per cent in Hong Kong where as in manufacturing it ranges from a low of -1.0 per cent to a high of 2.9 per cent in Korea.

5. McCombie (1980) suggests that intersectoral labour transfers could explain a substantial proportion of the observed differences in aggregate productivity growth among the advanced countries over the period 1951-73. McCombie (1991) argue that reallocation of labour from a low (agricultural) to a high productivity sector led to an increase in the rate of growth of aggregate productivity for purely arithmetical reasons.

4. Other papers focus on the role of intersectoral labour allocation in team/commune production vis-a-vis private plots or private sectors in general for China and Soviet Russia. See for example Bradley (1971), Bonin (1977), Chinn (1979), and Putterman (1980). These studies suggest equating marginal incomes from the two sectors, and the ratio of marginal utility of leisure to that of income (Liu, 1977). These papers doe not incorporate the level of effort explicitly in their model formulation.

6. Typically, for a sector in which output is fully shared among the agents and joint output is the only observable indicator of input, moral hazard problems will occur even when there is no uncertainty over the outcome of the production process. Non-cooperative behaviour among the members of a team will yield inefficient outcomes as emphasized in Holmstrom (1982). We abstract from these moral hazard problems here. These incentive effects of average product sharing rules are also discussed in Ireland and Law (1980).

7. We use the Hicksian equivalent variation as our measure of welfare. 